\title{
PRODUTIVIDADE, INCIDÊNCIA DE PODRIDÃO-PARDA E DANOS POR PRAGAS EM PÊSSEGO CULTIVADO SOB PRODUÇÃO INTEGRADA ${ }^{1}$
}

\author{
LOUISE LARISSA MAY DE MIO ${ }^{2}$, FRANCINE LORENA CUQUEL ${ }^{1}$, LINO BITTENCOURT \\ MONTEIRO $^{2}$, ANTONIO CARLOS VARGAS MOTTA ${ }^{2}$, BEATRIZ MONTE SERRAT ${ }^{2}$
}

RESUMO - O sistema de produção integrada (IP) é uma tecnologia que permite aumentar a segurança alimentar, diminuir a aplicação de produtos químicos e o impacto ambiental. Este trabalho comparou dois pomares de pêssego da cultivar Chimarrita, um deles sob produção integrada e o outro sob manejo convencional (CP), situados na Lapa, Paraná, Brasil. O manejo do pomar CP foi o usualmente aplicado pelos produtores locais, e o manejo IP foi o recomendado pelas Normas Brasileiras de Produção Integrada de Pêssego. Durante três safras (2002, 2003 e 2004), produtividade, calibre dos frutos, incidência de podridão parda e danos (causados por Grapholita, Anastrepha, lagartas e outras causas) foram quantificados em ambos os sistemas. O número de aplicações de inseticidas e fungicidas no CP foi maior que no IP, tal qual ocorreu com a incidência de podridão-parda. Grapholita molesta, Anastrepha spp. e lagartas foram mantidas sob controle durante as três safras. A produtividade, bem como o tamanho dos frutos, foram maiores no IP, indicando as vantagens desse sistema de produção.

Termos para indexação: fruta de caroço, manejo, Monilinia fructicola, Grapholita molesta, Anastrepha spp.

\section{PEACH PRODUCTIVITY, BROWN ROT INCIDENCE, AND PEST DAMAGE UNDER INTEGRATED PRODUCTION SYSTEM}

\begin{abstract}
The Integrated Production System (IP) is a technology that aims to increase food safety, diminish application of chemical products, and reduce the environmental impact. IP methods suitable for peach trees are scarce and recent in Brazil. The present research focused on comparing two 'Chimarrita' peach orchards, one managed under IP, and the other under conventional system management (CP) in Lapa, Parana, Brazil. CP orchard management was the usually applied by local grower's and IP orchard management was the recommended by the "Brazilian Norms for Integrated Peach Production". For three crops (2002, 2003, 2004), productivity, fruit caliper, brown rot incidence, and damages (caused by Grapholita molesta, Anastrepha spp., caterpillars, and others), were quantified in both managements. The pesticides and fungicides applications on CP were higher than on IP, and so did the brown rot incidence. G. molesta, Anastrepha spp., and caterpillars were kept under control during three crops in both systems. Productivity was higher and fruit size was larger under IP, indicating the advantage of such production system.
\end{abstract}

Index terms: stone fruit, management, Monilinia fructicola, Grapholita molesta, Anastrepha spp.

\section{INTRODUCTION}

Peach (Prunus persica L. Batsch) productivity and growing area have almost fourfold during last 40 years (DOLINSKI et al., 2005). Brazil is $12^{\text {th }}$ worldwide country in production, and the $22^{\text {nd }}$ in productivity, with an average of 8 ton/ha, while France, USA, Greece, Spain, and Italy produce 15 ton/ha (DOLINSKI et al., 2005). Those data indicate that is possible to improve Brazilian peach productivity investing in technology. Peach is grown in Brazil in almost 24,000 hectares (FAOSTAT, 2006), and
Parana State plants 1,611 hectares of peach trees producing an average of 10.85 ton/ha (SECRETARIA DO ESTADO DA AGRICULTURA E DO ABASTECIMENTO, 2011).

The most important disease affecting peaches in Parana State is brown rot, caused by the fungus Monilinia fructilola (Wint.) Honey. Its occurrence begins at the blossoming and goes on to the harvest period, having an important role in post-harvesting (OGAWA et al., 1995, MAY-DE MIO et al., 2004). The pathogen may infect branches, and causes direct losses, as result of flowers and fruits infection during

\footnotetext{
${ }^{1}$ Trabalho Sinfruit 053 - Simpósio Internacional de Fruticultura - Avanços na Fruticultura (17 a 21 Outubro)

${ }^{2}$ Associate Professor, Federal University of Paraná (UFPR), Rua dos Funcionários, 1540, Curitiba- PR, Zip Code 80.035-050 Brazil.

E-mail: maydemio@ufpr.br; francine@ufpr.br; lbmonte@terra.com.br; mottaacv@ufpr.br; bmserrat@ufpr.br
} 
pre-harvest, harvest and post-harvest, and may affect the whole production, if not controlled (MOREIRA, 2005). The main period in which the chemical control of this disease is carried out in field, covers blossoming and pre-harvest, with fungicides like benzimidazol, dicarboximide, triazol, and estrobilurine group (LARENA et al., 2005; MOREIRA; MAY-DE MIO, 2006). Besides that, the most important pest in peach orchards are grapholita (Grapholita molesta) (POLTRONIERI et al., 2008); and fruit-flies (Anastrepha spp.) (MONTEIRO et al., 2007).

Integrated Production System (IP) is a technology that aims to increase food safety, diminish application of chemical products, and reduce environmental impact by applying pest monitoring, less toxic products, and the alternation of chemicals applied. In Brazil it is normalized by the National System of Integrated Fruit Production (FACHINELLO et al., 2003a), but little is known about peach productivity, pest and diseases occurrence under IP comparing with conventional system (CP). The present work aimed to compare two 'Chimarrita' peach orchards, one managed under IP and the other under CP at Lapa County, Parana, Brazil.

\section{MATERIALS AND METHODS}

This research was carried out in Lapa County ( $25^{\circ} 46^{\prime} \mathrm{S}$ and $49^{\circ} 43^{\prime} \mathrm{W}, 907$ meters height), Parana State, Brazil, in a four years old 'Chimarrita' peach orchard from 2002 to 2004.

The fruit orchard was handled in two parts of 9 lines with 60 plants each, for each production system, one carried out in $\mathrm{CP}$ and the other carried out according to the National System of Integrated Fruit Production (FACHINELLO et al., 2003a). Central lines of each system were sub-divided into 10 blocks of 14 plants, and 30 plants/systems of production were evaluated in each part, in a space of $3 \times 6 \mathrm{~m}$. Both management systems are characterized as follows:

$\mathrm{CP}$ - usual crop practices used by local growers were adopted, that means, pest and disease control treatments without any monitoring to establish when chemical products should be applied, in a steady calendar, fertilizers were applied following the local growers' regular method and quantities, interlines were free of spontaneous vegetation in the interline by frequent herbicides applications.

IP - crop practices followed recommendations issued by National System of Integrated Fruit Production (FACHINELLO et al., 2003a). Several steps were taken to fulfill IP practices: pest and disease were monitored to establish when chemical products should be applied, fertilizer application was recommended based on soil and foliar analysis, minimum soil work (cleared in the interline, and 2 annually applications of herbicide in line at most) was performed, green pruning was done, and all activities carried out in the orchard were registered on a field book.

Fruits damaged by brown rot were assessed and discharged before each harvest. At the harvest, productivity, fruit caliber, and fruit damage caused by G. molesta, Anastrepha spp, caterpillars, and others (mechanical damage, physiological deformities, birds and hail) were evaluated. The caliber was classified according to fruit diameter: $0=\leq 3.5 \mathrm{~cm} ; 1=$ 3.5 to $4.5 \mathrm{~cm} ; 2=4.6$ to $5.0 \mathrm{~cm} ; 3=5.1$ to $5.5 \mathrm{~cm} ; 4$ $=5.6$ to $6.0 \mathrm{~cm} ; 5=6.1$ to $6.6 \mathrm{~cm} ; 6=6.7$ to $7.3 \mathrm{~cm}$; $7=7.4$ to $8.0 \mathrm{~cm} ; 8=\geq 8.0 \mathrm{~cm}$. Statistical analysis was performed through Generalized Linear Models (McCULLAGH; NELLDER, 1983). The difference between both production systems was tested comparing the deviation of patterns with and without this effect, after adjusting for tree and weather effects.

\section{RESULTS AND DISCUSSION}

\section{Applications of pesticides and fungicides}

Pesticide and fungicide applications on $\mathrm{CP}$ were higher than on IP (TABLE 1). This is certainly due to the IP management carried out in traps, which allowed monitoring pest incidence during all seasons. Besides that, the choice of more specific, efficient, and environmental-friendly chemical products for each target disease helped maintaining biological control, such as recommended by Agrios (1997).

\section{Brown rot incidence}

Brown rot was efficiently controlled at blossoming, showing just a small occurrence of $1 \%$ in third year (data not shown). Smaller brown rot incidence on IP (TABLE 2) may be attributed to permanent removal of orchard's fruit with this disease symptom such as is recommended by Souza et al. (2007) and Kowata et al. (2011). It is important to observe that in all crops there was also lower brown rot incidence, even with less fungicide applications (TABLE 1). Those data are in accordance with Williams et al. (1992), who reported that on peach tree orchards, IP handling management was better for disease control, with a reduction of $10 \%$ in brown rot incidence and Hogmike and Biggs (1994), who managed peach pests and diseases using $\mathrm{CP}$, obtained similar results comparing to IP with $51 \%$ less pesticide application. 


\section{Fruit damage}

Damage caused by G. molesta was similar in both systems during first two years assessed, and lower in third year (TABLE 3), showing IP advantage. In same way, caterpillars were better controlled under IP (TABLE 3). The lower caterpillar damage might be explained by the more ecological management of spontaneous vegetation in the row middles. The mechanical damage, physiological deformities, and caused by birds or hail were similar in both systems (TABLE 3). In 2004 mechanical damage was much higher comparing with two others years due to a hail storm.

\section{Production assessment}

Number of fruits per plant and productivity in first and second years were highest under IP (TABLE 4). Certainly it is due to fertilization based on soil and foliar analysis and the green pruning.

Fruit produced under IP were biggest than under CP (TABLE 5). These results agree with those obtained by Farias et al. (2003) working with 'Marli' peach fruits in South of Brazil, and with Fachinello et al. (2003b) working with 'Diamante' peach fruits also in South of Brazil.

The production results obtained in this work are promising, considering that with three IP crops it was possible to obtain a bigger production with less environmental impact due to reduced application of pesticides and fungicides (TABLE 1).

TABLE 1 - Fungicides and pesticides applications per year in a 'Chimarrita' peach orchard managed under conventional system (CP) and integrated production system (IP) (Lapa, Paraná, Brazil).

\begin{tabular}{ccccc}
\hline \multirow{2}{*}{ Chemical } & Management & \multicolumn{3}{c}{ Applications number } \\
\cline { 3 - 5 } & & 2002 & 2003 & 2004 \\
\hline Pesticides & $\mathrm{CP}$ & 5 & 3 & 4 \\
& $\mathrm{IP}$ & 2 & 2 & 1 \\
\multirow{3}{*}{ Fungicides } & $\mathrm{CP}$ & 10 & 12 & 11 \\
& $\mathrm{IP}$ & 6 & 7 & 6 \\
\hline
\end{tabular}

TABLE 2 - Brown rot incidence per year (\%) in a 'Chimarrita' peach orchard managed under conventional system (CP) and integrated production system (IP) (Lapa, Paraná, Brazil).

\begin{tabular}{lccc}
\hline \multirow{2}{*}{ Management/ year } & 2002 & 2003 & 2004 \\
\cline { 2 - 4 } & 3.63 & 9.35 & 24.8 \\
$\mathrm{CP}$ & $2.44^{* *}$ & $3.5^{* *}$ & $10.2^{*}$ \\
\hline $\mathrm{IP}$ &
\end{tabular}

*Averages difference at $5 \%$, and ** averages difference at $1 \%$ by the standard deviation analysis.

TABLE 3 - Fruit damage per year (\%) in a 'Chimarrita' peach orchard managed under conventional system $(\mathrm{CP})$ and integrated production system (IP) (Lapa, Paraná, Brazil).

\begin{tabular}{|c|c|c|c|c|c|c|c|c|c|c|c|}
\hline \multirow{3}{*}{$\begin{array}{l}\text { Cause } \\
\text { Management/ } \\
\text { year }\end{array}$} & \multicolumn{11}{|c|}{ Fruit damage (\%) } \\
\hline & \multicolumn{2}{|c|}{ Grapholita molesta } & \multicolumn{3}{|c|}{ Anastrepha spp } & \multicolumn{3}{|c|}{ Caterpillars } & \multicolumn{3}{|c|}{ Others $^{1}$} \\
\hline & 20022003 & 2004 & 2002 & 2003 & 2004 & 2002 & 2003 & 2004 & 2002 & 2003 & 2004 \\
\hline $\mathrm{CP}$ & $2.6 \quad 0.0$ & 4.3 & 0.09 & 0.0 & 2.1 & 4.7 & 15.8 & 0.0 & 2.5 & 3.2 & 54.7 \\
\hline IP & $3.2^{\mathrm{ns}} 0.4^{\mathrm{ns}}$ & $2.0 *$ & $0.08^{\mathrm{ns}}$ & $0.0^{\mathrm{ns}}$ & $2.9^{\mathrm{ns}}$ & $3.2^{*}$ & $8.7^{*}$ & $0.0^{\mathrm{ns}}$ & $2.4^{\mathrm{ns}}$ & $\begin{array}{r}1.8 \\
\text { ns }\end{array}$ & $51.7^{\mathrm{ns}}$ \\
\hline
\end{tabular}

*Averages difference at $5 \%$, and ${ }^{\text {ns }}$ averages do not differ significantly between each other

${ }^{1}$ Mechanical damage, physiological deformities, and caused by birds and hail. 
TABLE 4 - Number of fruits/plant and productivity (ton/ha) of a 'Chimarrita' peach orchard managed under conventional system (CP) and integrated production system (IP) (Lapa, Paraná, Brazil).

\begin{tabular}{lcrrr}
\hline & Management/year & 2002 & 2003 & 2004 \\
\cline { 2 - 5 } Number of fruits/plant & CP & 196.9 & 285.7 & 373.6 \\
& IP & $267.0^{*}$ & $378.6^{*}$ & $391.8^{\mathrm{ns}}$ \\
Productivity (ton/ha) & CP & 11.9 & 14.1 & 19.7 \\
& IP & $16.1^{*}$ & $21.5^{*}$ & $20.9^{\mathrm{ns}}$ \\
\hline
\end{tabular}

*Averages difference at $5 \%$, and ${ }^{\text {ns }}$ averages do not differ significantly between each other.

TABLE 5 - Fruit caliber (\%) from a 'Chimarrita' peach orchard managed under conventional system (CP) and integrated production system (IP) (Lapa, Paraná, Brazil).

\begin{tabular}{lccccccc}
\hline Fruit/caliber (\%) & Management & 2 & 3 & 4 & 5 & 6 & 7 \\
\hline 2003 & CP & 0.0 & 0.7 & 6.2 & 41.3 & 47.1 & 4.7 \\
& IP & $0.0^{\text {ns }}$ & $0.7^{\text {ns }}$ & $4.0^{\text {ns }}$ & $32.2^{*}$ & $56.7^{*}$ & $6.4^{*}$ \\
2004 & CP & 5.9 & 27.0 & 44.1 & 19.6 & 3.3 & 0.0 \\
& IP & $0.5^{*}$ & $5.8^{*}$ & $27.0^{*}$ & $40.9^{*}$ & $24.0^{*}$ & $1.6^{*}$ \\
2005 & CP & 0.7 & 15.7 & 59.6 & 19.8 & 4.0 & 0.0 \\
& IP & $0.6^{\text {ns }}$ & $14.5^{\text {ns }}$ & $60.2^{*}$ & $19.9^{\text {ns }}$ & $4.6^{*}$ & $0.0^{\text {ns }}$ \\
\hline
\end{tabular}

\section{CONCLUSIONS}

The applications of pesticides and fungicides on CP were higher than on IP, without losing its efficiency in controlling brown rot, Grapholita molesta and Anastrepha spp. Productivity and fruit size were best under IP, indicating the advantage of such production system.

\section{ACKNOWLEDGEMENTS}

To the Agriculture, Cattle Raising and Supply Ministry (MAPA), to the National Council for Scientific and Technological Development (CNPq) for the financial support to the project, and also to all Universities' collaborators from Federal University of Pelotas (UFPel), Federal University of Rio Grande do Sul (UFRGS), Brazilian Agricultural Research Company (EMBRAPA - CNPUV), Brazilian Company of Technical Assistance (EMATER-PR), and State Secretary for Agriculture and Supply (SEABPR). Special thanks to the Engineer Edir Buske, orchard owner where this research was developed.

\section{REFERENCES}

AGRIOS, G.N. Plant pathology. 4.ed. New York: Academic Press, 1997. 635p.

DOLINSKI, M.A.; MONTE SERRAT, B.; MOTTA, A.C.V.; CUQUEL, F.L.; SOUZA, S.R.; MAY-DE MIO, L.L.; MONTEIRO, L.B. Produção, teor foliar e qualidade de frutos do pessegueiro 'Chimarrita' em função da adubação nitrogenada, na região da Lapa - PR. Revista Brasileira de Fruticultura, Jaboticabal, v. 27, n. 2, p. 295 -299, 2005.

FACHINELLO, J.C.; COUTINHO, E.F.; MARODIN, G.A.B.; BOTTON, M.; MAY-DE MIO, L.L. Normas técnicas e documentos de acompanhamento da produção integrada de pêssego. Pelotas: Signus Comunicação Ltda, 2003a.

FACHINELLO, J.C.; TIBOLA, C.S.; VICENZI, M.; PARISOTTO, E.; PICOLOTTO, L.; MATTOS, M.L.T. Produção Integrada de pêssegos: três anos de experiência na região de Pelotas - RS. Revista Brasileira de Fruticultura, Jaboticabal, v. 25, p. 256-258, 2003 b. 
FAOSTAT. FAO Statistics Division 2006. Disponível em: <http://faostat.fao.org>. Acesso: set. 2006.

FARIAS, R.M.; NUNES, J.L.S.; MARTINS, C.R.; GUERRA, D.S.; ZANINI, C.; MARODIN, G.A.B. Produção convencional $\mathrm{x}$ integrada em pessegueiro cv. Marli na depressão central do Rio Grande do Sul. Revista Brasileira de Fruticultura, Jaboticabal, v. 25 , p. 253-255, 2003.

HOGMIRE, H.W.; BIGGS, A.R. Reduced pesticide program for peach based on tree phenology. Crop Protection, London, v. 13, p. 277-280, 1994.

KOWATA, L. S.; AMORIM, L.; FACHINELLO, J. C.; MAY-DE MIO, L. L. Implementação do sistema de produção integrada de pêssegos no Paraná, Bragantia, Campinas, v. 70, n. 2, 2011.

LARENA, I.; TORRES, R.; DE CALL, A.; LIÑÁN, M.; MELGAREJO, P.; DOMENICHINI, P.; BELLINI, A.; MANDRIN, J. F.; LICHOU, J.; DE ERIBE, X. O.; USALL, J. Biological control of postharvest brown rot (Monilinia spp.) of peaches by field applications of Epicoccum nigrum. Biological Control, Orlando, v. 32, p. 305-310, 2005.

MAY-DE MIO, L.L.; GARRIDO, L.; UENO, B. Doenças de Fruteiras de Caroço. p. 169 - 221. In: MONTEIRO, L.B.; MAY-DE MIO, L.L.; MONTE SERRAT, B.; MOTTA, A.C.V.; CUQUEL, F.L. (Ed.). Fruteiras de caroço: uma visão ecológica. Curitiba: UFPR, 2004.

McCULLAGH P.; NELLDER, J.A. Generalized linear models. London: Chapman and Hall, 1983. 206p.

MONTEIRO, L.B.; MAY-DE MIO, L.L.; MOTTA, A. C.V.; MONTE SERRAT, B.; CUQUEL, F.L. Avaliação de atrativos alimentares utilizados no monitoramento de mosca-das-frutas em pessegueiro na Lapa- PR. Revista Brasileira de Fruticultura, Jaboticabal, v. 29, n.1, p. 72-74. 2007.
MOREIRA, L.M. Alternativas de controle integrado da podridão-parda do pessegueiro. 2005. 113f. Tese (Doutorado) - Universidade Federal do Paraná, Curitiba, 2005.

MOREIRA, L.M.; MAY-DE MIO, L.L. Efeito de fungos antagonistas e produtos químicos no controle da podridão-parda em pomares de pessegueiro. Revista Floresta, Curitiba, v. 36, p. 287-293. 2006.

OGAWA, J.M.; ZEHR, E.I.; BIRD, G.W.; RITCHIE, D.F.; URIU, K.; UYEMOTO, J.K. Compendium of stone fruit diseases. St Paul: The American Phytopathological Society, 1995.

POLTRONIERI, A.S.; SCHUBER, J. M.; MONTEIRO, L. B.; MAY-DE MIO, L.L. Danos de Grapholita molesta (Busck) (Lepidoptera: Tortricidae) em seis cultivares de pessegueiro em Araucária, Paraná. Revista Brasileira de Fruticultura, Jaboticabal, v.30, n.4, p. 897-901, 2008.

\section{SECRETARIA DO ESTADO DA AGRICULTURA} E DO ABASTECIMENTO. Produção agropecuária. Disponível: $<\mathrm{http} / /$ www.seab.pr.gov.br/modules/conteudo/conteudo.php?conteudo $=137>$. Acesso em: 02 jun. 2011.

SOUZA, S. R.; MAY-DE MIO, L.L.; SERRAT, B.M.; CHALLIOL, M.A. Doenças foliares, cancro e número de frutos relacionados com a adubação nitrogenada em pessegueiro. Revista Brasileira de Fruticultura, Jaboticabal, v.29, p.260-264, 2007.

WILLIAMS, W.T.; CIFUENTES, S.; DELAGUILA, V.; PEREZ, R. Rejuvenation of a peach orchard in the highlands of Guatemala through integrated management. Tropical Agriculture, London, v. 69, p. 341-346. 1992. 